УДК 517.946 .9

\title{
The mathematical model of the thermal process in Spoke-Type Permanent Magnet Synchronous Machines
}

\author{
${ }^{1}$ Olga Demyanchenko, ${ }^{2}$ Elena Kobilskaya, ${ }^{2}$ Viktor Lyashenko, ${ }^{2}$ Tetiana Nabok \\ ${ }^{1}$ Mariupol, Azov maritime institute of National university "Odessa maritime academy", \\ 13 Stroiteley str., 87517 Mariupol, Ukraine \\ ${ }^{2}$ Kremenchuk Mykhailo Ostrohradsky National University, \\ 20 Pershotravneva str., 39600 Kremenchuk, Ukraine \\ kobilskaya1983@gmail.com
}

\begin{abstract}
This paper presents an mathematical model for the prediction of temperature field distribution in spoke-type permanent magnet synchronous machines. The mathematical model takes into account radial heat transfer streams; it is presented as a boundary problem in a multilayer non-canonical region with conjugation conditions at the boundaries of the layers, with different thermal physical properties. The entire study area is divided into five types of simple subdomains, including a shaft, an inner fan-shaped magnet, an outer fan-shaped magnet, a slot opening and a slot. Moreover, on the border of the inner and outer fanshaped magnets in slot opening and a slot, we have an perfect thermal contact. The problem is solved by the finite element method. Using the results of numerical experiments, the model allows you to control the temperature field of the machine, allows you to calculate the temperature distribution in its individual parts.
\end{abstract}

Key words: electric machine, mathematical model, temperature field, finite element method.

У роботі представлена математична модель розподілу температурного поля в синхронній машині з постійним, у формі спиць, магнітом. Математична модель враховує як радіальний так і осьовий потоки передачі тепла і представляє собою крайову задачу в багатошаровій неканонічній області з умовами спряження на границях шарів, 3 різними теплофізичними властивостями. Вся область дослідження розділена на п'ять типів простих підобластей, а саме вал, внутрішній віялоподібний магніт, зовнішній віялоподібний магніт, пазовий отвір і паз. Причому, на границі внутрішнього і зовнішнього віялоподібних магнітів пазового отвору і пазу має місце ідеальний тепловий контакт. В даній машині 4 пари полюсів і 9 слотів. Джерело тепла рівномірно розподілено в обмотках статора.У центрі слота розташовується обмотка, площа якої дорівнює сумі площ всіх мідних проводів. Задача розв'язується методом кінцевих елементів. У порівнянні з існуючими математичними моделями теплових процесів в синхронній машині 3 постійним, у формі спиць, магнітом, оригінальність цього дослідження полягає в побудові комплексної теплової моделі, яка враховує характер теплового обміну на межі розділу складових частин машини. Результати проведених досліджень $\epsilon$ основою для проектування синхронної машини 3 постійним, у формі спиць, магнітом, розробки алгоритму керування температурним полем синхронної машини, дозволяють враховувати температурні ефекти, особливо в тих підобластях, де робоча температура може змінюватися. Запропонована математична модель температурного поля в електричній машині дозволяє контролювати температуру в режимі реального часу. Модель дозволяє розраховувати температуру окремих частин машини, що важливо для швидкого регулювання умов ii експлуатації і охолодження.

Ключові слова: електрична машина, математична модель, температурне поле, метод кінцевих елементів.

В данной статье представлена математическая модель распределения температурного поля в синхронных машинах с постоянными спицевидными магнитами. Математическая модель учитывает как радиальный так и осевой потоки передачи тепла и представляет собой краевую задачу в многослойной неканонической области с условиями сопряжения на границах слоев, с различными теплофизическими свойствами. Вся область исследования делится на пять типов простых подобластей, включая вал, внутренний веерообразный магнит, внешний веерообразный магнит, пазовое отверстие и паз. Причем, на границе внутреннего и внешнего веерообразных магнитов пазового отверстия и паза имеет место идеальный тепловой контакт. Задача решается методом конечных элементов. Модель позволяет рассчитывать температуру отдельных частей машины, что важно для быстрого регулирования условий ее эксплуатации и охлаждения.

Ключевые слова: электрическая машина, математическая модель, температурное поле, метод конечных элементов.

\section{Introduction}

High-speed electric machines with excitation from permanent magnets are widely used in various industries, including automotive industry. Recently, interior permanent magnet synchronous motors have become known as a good candidate for hybrid electric vehicle traction drive application due to their unique merits. Synchronous electric machine with different geometry and permanent magnets (PMSG) became the object of numerous studies. In this paper we consider electric machine with a spoke-type PM rotor and an internal permanent magnet [1-2]. In [1-2] the magnetic field in the spoketype PM rotor is investigated, and an attempt to account for the impact of the end effects (form of end winding reactance or magnetic leakage flux) in a two dimensional approximation is made. In [1] presents an analytical model for the prediction of magnetic field distribution in spoke-type permanent magnet synchronous machines with rectangular magnets and magnetic bridges. In [3] mainly 
investigates the equivalent stator slot model used in temperature field of high torque-density permanent magnet synchronous in-wheel motor. Based on the law of heat transfer in stator slot, a new layered winding model is put forward in this paper. For high torque-density permanent magnet synchronous inwheel motor, service life and electromagnetic performance are related directly to winding temperature [2]. With high efficiency and power density, interior permanent magnet (IPM) synchronous machines have been employed in many commercialized electrified power trains [4-5]. The interior permanentmagnetic motor is widely used for electric vehicles.

In [6] mainly analyzes the thermal field distribution of two conditions: the rated speed and rated load condition; the low speed and rated load condition. In [7], the influences of temperature variation on the characteristics and performance of spoke-type interior permanent magnet (IPM) machines are analyzed. Key machine performance metrics, such as flux linkages, torque, and inductances variation as functions of the temperature are simulated and discussed. However, in all these works, the complete mathematical model of the thermal process in the permanent magnet synchronous machines was not considered, with the help of which it was possible to determine the temperature regime at any point of it.

In [7-8], a mathematical model of the thermal process in an electric machine is constructed, which is presented in the form of a three-layer cylinder, in which in one layer the internal heat sources operate, while the heat is transferred to another by thermal conductivity. The method for solving boundary value problems for the heat conduction equation in a complex region is a multilayer cylinder, where in one part of the layers the internal sources of heat act, and in the other external ones, is proposed. The method of solving the problem in conditions of uncertainty (absence) of one of the boundary conditions on the boundary of the layers with conductive heat exchange between the layers is proposed. The essence of the method is to average the temperature distributions along the radius in the inner layers. As a result of transformations at the boundary of the layers, the boundary condition of the conjugation of the impedance type appears. In [9] a mathematical model of the temperature field of the radial section of an electric machine is constructed; the temperature distributions are considered in the individual subdomains of the machine, and then the summation of the resulting solutions takes place. In this work a complete mathematical model of the thermal process in synchronous machines with spoke-type permanent magnet is investigated. Knowledge of temperature distributions in the windings and in the air gap is very important for designing an electric machine and analyzing its temperature field of the machine as a whole. Stator and rotor sheets have open, semi-closed or closed grooves in which current conductors (windings) are located. In the stator most commonly used are semi-enclosed grooves of rectangular or oval shape, in high-power machines - open grooves of a rectangular shape. The distribution of the conductors in the slots has a certain influence on the maximum temperature of the windings [10].

In comparison with other studies [11-15] of thermal processes in a permanent magnet synchronous machine, the originality of this study is to construct a complete mathematical model of the thermal process in synchronous machines. Moreover, the synchronous machine is represented as a multi-layered region with different thermal physical characteristics of the layers. Let's consider a synchronous machine with a spoke type permanent magnet rotor in the form as in [1]. Figure1 shows an example spoke type permanent magnet rotor.

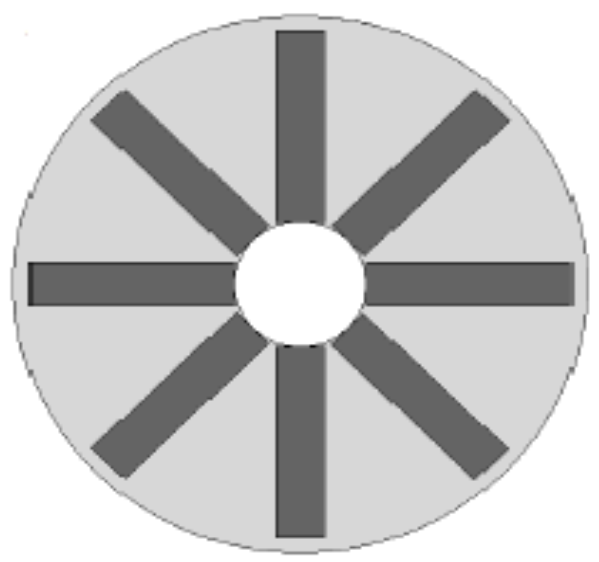

Figure 1. Spoke type permanent magnet rotor with eight poles 


\section{Purpose of the Paper}

The purpose of this paper is to construct and investigate the complete mathematical model of the thermal process in spoke-type permanent magnet synchronous machines with four pairs of poles and nine slots, that takes into account the nature of the heat exchange at the interface between the parts of the machine.

\section{Study resources and results}

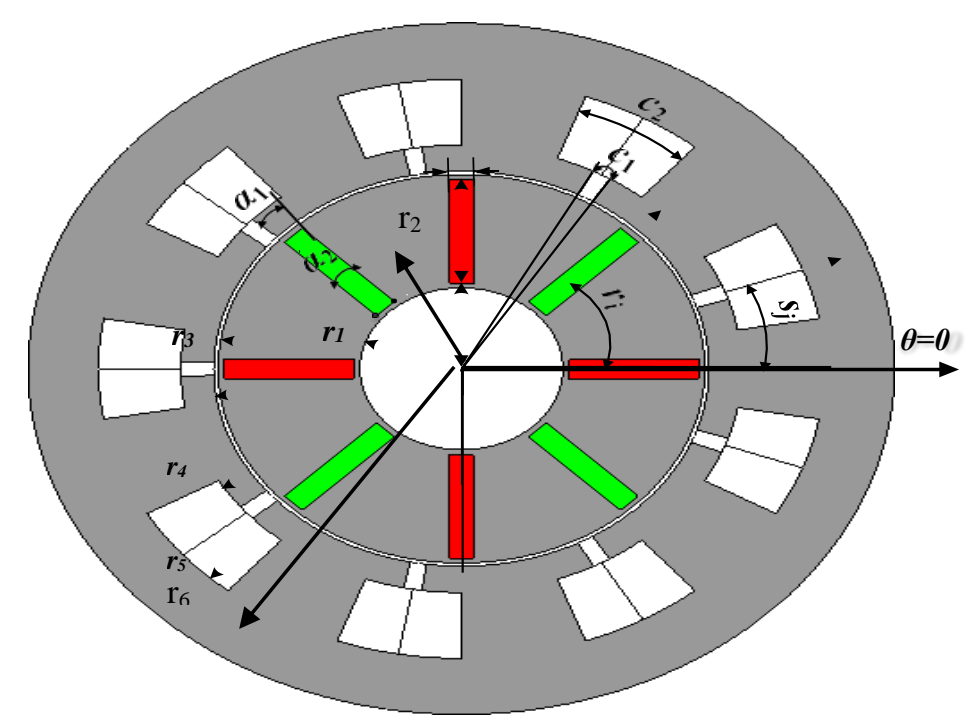

Figure 2. Machine geometry

In this paper, a mathematical model for the rotor shown in Figure 2 is constructed.

Fig. 2 shows the model with rectangular magnets and magnetic bridges [1], where $\theta$ is the circumferential position, the position of initial axis is defined as $\theta=0 ; r_{i}$ is the angular position of the $i$ th magnet with reference to initial axis; $s$ is the angular position of the $j$ th slot; $\alpha_{1}$ is the width angle of the magnet outer edge; $\alpha_{2}$ is the width angle of the magnet inner edge; $c_{1}$ is the slot opening width angle; $c_{2}$ is slot width angle; $r_{1}, r_{3}, r_{4}$ and $r_{5}, r_{6}$ are the radius of the shaft, stator bore, slot top and slot bottom, machine respectively.

To achieve the set goal, the entire field domain is divided into five types of simple subdomains, i.e. a shaft (I), an inner fan-shaped magnet (II), an outer fan-shaped magnet (III), a slot opening (IV) and a slot $(\mathrm{V})$. There are four pairs of poles and nine slots in the investigated machine. Besides, there is a perfect thermal contact on the boarder of the inner and outer fan-shaped magnets and the slot.

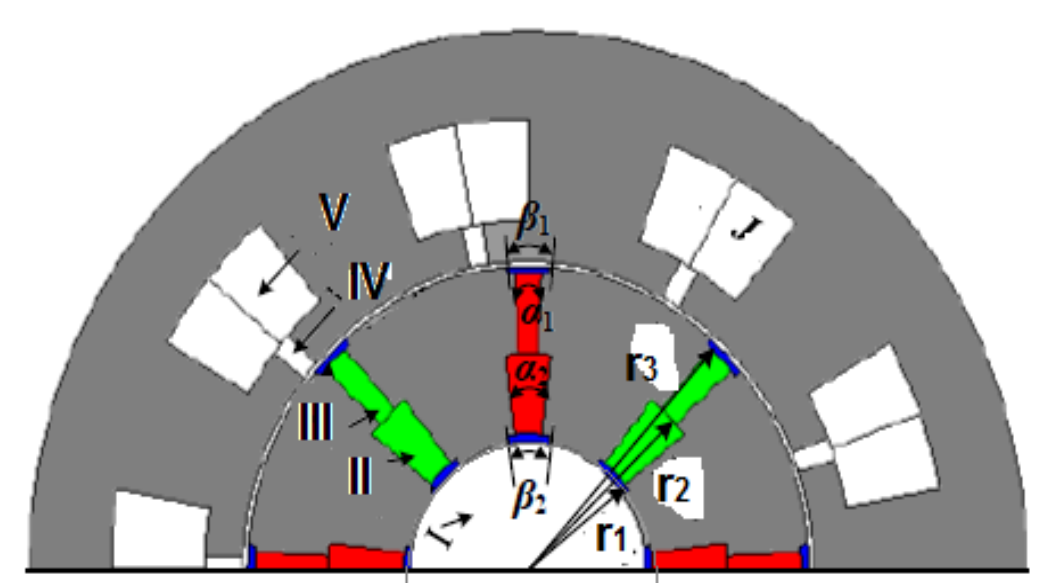

Figure 3. Subdomains of electric machine 
Determination of the temperature distribution $T(r, \varphi)$ in the multilayer region $\Omega:\left\{0<r<r_{6}, 0 \leq \varphi \leq 2 \pi\right\}$, where the internal heat source is concentrated in the windings, that is, in the region $\mathrm{V}$ can be written as a boundary value problem with conjugation conditions in the form

$$
\begin{gathered}
\lambda_{i} \frac{1}{r} \frac{\partial}{\partial r}\left(r \frac{\partial T_{i}}{\partial r}\right)+\lambda_{i} \frac{1}{r^{2}} \frac{\partial^{2} T_{i}}{\partial \varphi^{2}}=\left\{\begin{array}{l}
-\frac{I^{2} \rho_{0}}{S^{2}}, r_{4} \leq r<r_{5}, s_{j}-\frac{c_{2}}{2}<\varphi<s_{j}+\frac{c_{2}}{2}, j=1,2, . . \\
0, \quad 0<r<r_{1}, r_{5} \leq r<r_{6},(0<\varphi<2 \pi), r_{1}<r<r_{2},\left(r_{i}-\frac{\alpha_{2}}{2}<\varphi<r_{i}-\frac{\alpha_{2}}{2}\right) \\
r_{2}<r<r_{3},\left(r_{i}-\frac{\alpha_{1}}{2}<\varphi<r_{i}+\frac{\alpha_{1}}{2}\right), r_{3}<r<r_{4},\left(s_{j}-\frac{c_{1}}{2}<\varphi<s_{j}+\frac{c_{1}}{2}\right)
\end{array}\right. \\
\lambda T_{3 r}\left(\mathrm{r}_{3}, \varphi\right)=-\alpha\left(T_{3}-T_{c}\right)-\varepsilon \sigma\left(T_{3}^{4}-T_{c}^{4}\right), \\
T_{i r}\left(\mathrm{r}_{i}-0, \varphi\right)=T_{i r}\left(\mathrm{r}_{i}+0, \varphi\right), \\
T_{i}\left(r_{i}-0, \varphi\right)=T_{i}\left(r_{i}+0, \varphi\right), \quad i=1,2,4 \\
\lambda T_{4 r}\left(\mathrm{r}_{3}, \varphi\right)=-\alpha\left(T_{4}-T_{c}\right)-\varepsilon \sigma\left(T_{4}^{4}-T_{c}^{4}\right), \\
\lambda T_{5 r}\left(\mathrm{r}_{5}, \varphi\right)=-\alpha\left(T_{5}-T_{c}\right)-\varepsilon \sigma\left(T_{5}^{4}-T_{c}^{4}\right),
\end{gathered}
$$

$\lambda_{i}$-coefficients of heat conductivity of the rotor, stator iron, conductors of electric current and isolation, respectively, $T_{c}$ - ambient temperature, $\alpha_{i}, I, \rho_{0}, \varepsilon, \sigma-$ corresponding heat transfer coefficient, current strength, resistivity of current conductors, emissivity factor, Stefan-Boltzmann constant, $T_{1}-T_{5}-$ machine subdomain temperatures, $T_{1 r}-T_{5 r}$-temperature derivatives in the corresponding subdomains.

Here $S$ is the area of the slot, that is, the region V. For the calculations parameters were taken from [1]. The following assumptions for calculating the temperature field were taken using the finite element method. Convective and radiation heat exchange is considered. Radiation heat transfer always occurs, especially when the speed of rotation of the rotor is very small or the rotor is still. The heat source is evenly distributed in the stator windings. In the center of the slot is a winding, the area of which is equal to the total area of all copper wires.

TABLE 1.Thermal parameters of the machine materials

\begin{tabular}{|l|l|c|}
\hline Postion & Materials & K) \\
\hline Shaft & $45 \#$ & 50.2 \\
\hline Rotor core & DW 310-35 & 42.5 \\
\hline Winding copper & copper & 387 \\
\hline
\end{tabular}

The solution of the problem (1) - (6) in the Partial Differential Equation (PDE) Toolbox is implemented with the purpose of finite elements [16-18].

At first, the complex form of the region is constructed by combining intersection and subtraction operations. Then we set Equation 1 and, after specifying the coefficients of the differential equation, construct the computing grid using the Delaunay triangulation. The fundamental property is the Delaunay criterion. In the case of 2-D triangulations, this is often called the empty circumcircle criterion. For a set of points in 2-D, a Delaunay triangulation of these points ensures the circumcircle associated with each triangle contains no other point in its interior. 
We divide the domain $\Omega$ into triangles $\Delta_{i}, i=1,2, \ldots n$. Such a partition is called triangulation. Triangles with two vertices on the boundary of the region may have a curved side. We replace this side with a segment of a straight line and denote the resulting region by $\bar{\Omega}_{n}$. The vertices of the triangles are called triangulation nodes, we number them and let D1 be the set of nodes belonging to the boundary, D2 is the set of internal nodes, $D=D_{1} \cup D_{2}-$ set of all knots of triangulation. Further, finite elements are constructed, in this case triangles.

Consider any triangle $\Delta_{i} \subset \bar{\Omega}_{n}$. For each vertex of this triangle we define the function $\psi_{j}^{i}(r, \varphi)$, equal to one at this vertex and equal to zero at other vertices (here $i$ is the number of the triangle, $\mathrm{j}$ is the number of the vertex in the set of all nodes $D$ ). The simplest such function is a linear function in the form $z=a r+b \varphi+c$, moreover, $\mathrm{z}=1$ in one of the vertices of the triangle and $\mathrm{z}=0$ in the other two vertices. We associate an arbitrary parameter to the jth node, $\bar{u}_{j}, j=1, \ldots J$ Let the vertices of a triangle $\Delta_{i}$ have in the set D numbers $\mathrm{j} 1, \mathrm{j} 2, \mathrm{j} 3$. We define a new function

$$
\varphi_{i}(r, \varphi)=\left\{\begin{array}{l}
\bar{u}_{j 1} \psi_{j 1}^{i}(r, \varphi)+\bar{u}_{j 2} \psi_{j 2}^{i}(r, \varphi)+\bar{u}_{j 3} \psi_{j 3}^{i}(r, \varphi),(r, \varphi) \in \Delta_{i} \\
0, \quad(r, \varphi) \notin \Delta_{i}
\end{array}\right.
$$

The function $\varphi_{i}(r, \varphi)$ is called the finite element. After the region $\Omega$ was triangulated, a finite element mesh was regularized. The finite element mesh was rearranged in such a way that the irregularity of all finite elements does not exceed the value set in the PDE Tool. Then we build the system of equations.

Figure 4 shows that the highest temperature is observed in the windings of an electric machine. A significant proportion of failures of the electric machine is associated with the stator windings. The statistics of failures in the operation of an electric machine indicates that they occur due to overheating of the windings during operation. The temperature of the electric machine during operation increases with increasing current strength of the device; this can be caused by a decrease in the supply voltage to $95 \%$ and below.

Color: u

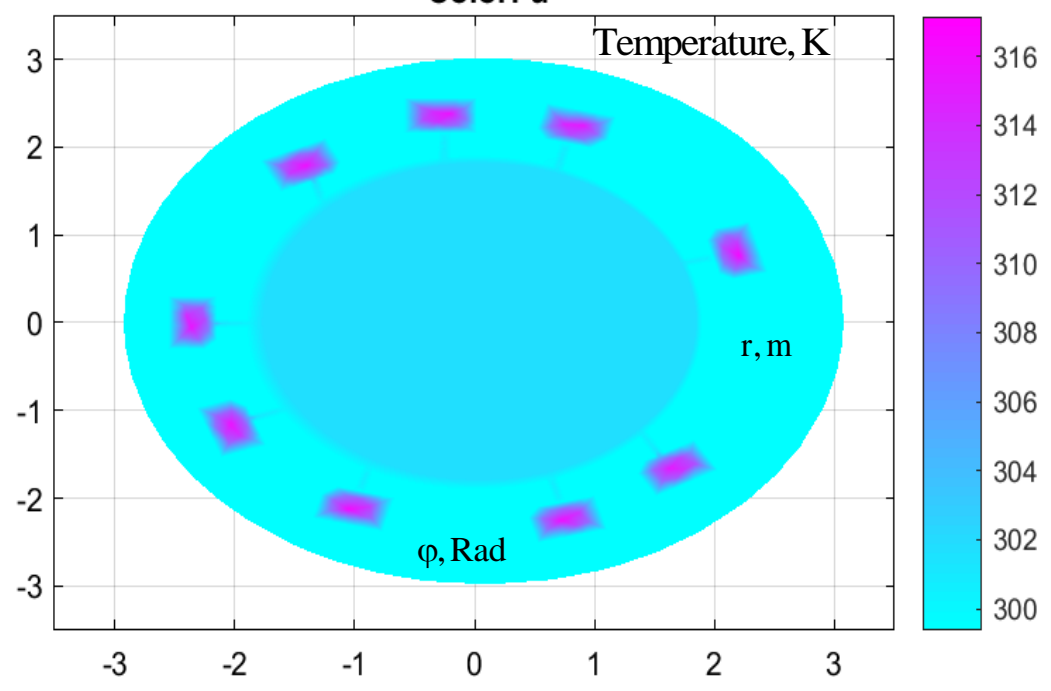

Figure 4. Solution of the problem (1) - (6), with the following working parameters of the electric machine 
$I=6 A$ Current density in DRM slots $J=10^{6} \frac{A}{\mathrm{~m}^{2}}$. Number of pole pairs 4, number of slots 9 . Geometric dimensions of the electric machine as in [1].

\section{Conclusions}

In this article a complete mathematical model of the thermal process in spoke-type permanent magnet synchronous machines is proposed. The investigated field consists of five subdomains. There is an ideal thermal contact on the border of the inner and outer fan-shaped magnets, the opening slot and the slot. When describing this ideal thermal contact, boundary conditions consider the equality of temperatures and feat flow on the surfaces. The boundary conditions of the fourth kind essentially give the rule of coupling of temperature fields of the study volume and the external body, where the heat is transferred by heat conduction. The problem is solved by the finite element method. The solution to the problem described in the mathematical model is implemented in the Partial Differential Equation (PDE) Toolbox. To implement the solution algorithm, a regularized computational grid was constructed using Delaunay triangulation. The results and trends shown in this research paper set a foundation for developing control algorithm which takes the temperature effects into consideration, especially in the applications where operating temperature varies significantly. This proposed mathematical model of the temperature field allows to control temperature in machine. The model allows to calculate the temperature of individual parts of the machine. This is important for quick adjusting its operating and cooling conditions.

\section{REFERENCES}

1. Peixin Liang, Feng Chai, Yi Li, and Yulong Pei, "Analytical Prediction of Magnetic Field Distribution in Spoke-Type Permanent-Magnet Synchronous Machines Accounting for Bridge Saturation and Magnet Shape", IEEE Trans.on Industrial Electronics, vol. 64, Issue 5, pp. 3479 3488, 2017.

2. Petter Eklund, Jonathan Sjölund, Sandra Eriksson, Mats Leijon, "Magnetic End Leakage Flux in a Spoke Type Rotor Permanent Magnet Synchronous Generator", International Scholarly and Scientific Research \& Innovation, vol. 11, no 3, pp. 605-610, 2017.

3. Peixin Liang,Yulong Pei, Feng Chaiand Shukang Cheng, "Equivalent stator slot model of temperature field for high torque-density permanent magnet synchronous in-wheel motors accounting for winding type", COMPEL International Journal of Computations and Mathematics in Electrical, vol.35, no 2, pp. 3457-3462, 2016.

4. N. Bracikowski, M. Hecquet, P. Brochet, and S. V. Shirinskii, "Multiphysics Modeling of a Permanent Magnet Synchronous Machine by Using Lumped Models", IEEE Trans. Ind. Electron, vol. 59, no. 6, pp. 2426-2437, 2012.

5. T. Sun and J. Wang, "Extension of Virtual-Signal-Injection-Based MTPA Control for Interior Permanent-Magnet Synchronous Machine Drives Into the Field-Weakening Region", IEEE Trans. Ind.Electron., vol. 62, no. 11, pp. 6809-6817, 2015.

6. Jingang Bai, Yong Liu, Yi Sui, Chengde Tong, Quanbin Zhao and Jiawei Zhang, "Investigation of the Cooling and Thermal-Measuring System of a Compound-Structure Permanent-Magnet Synchronous Machine", Energies, vol. 7, pp. 1393-1426, 2014.

7. Viktor Lyashenko, Elena Kobilskaya, Maryna Martynenko And Olga Demyanchenko, "Thermal process mathematical model in electrical machine", in Proceedings of the International Conference MEES'17, IEEE, Kremenchuk, 2017, pp. 296-299.

8. A. Zaika, O. Hrytsiuk, E. Kobilskaya, and V. Lyashenko, "The generalized mathematical model of heat conduction in a complex multi-layered area", AIP Conference Proceedings. vol. 1895, pp. 090004-090014, 2017.

9. A. Zaika, O. Demyanchenko ,O. Hrytsiuk, E. Kobilskaya, and V. Lyashenko, T. Hryhorova, "Mathematical model of heat transfer in an electric machine", AIP Conference Proceedings. vol. 2025, pp. 080006-1-080006-7, 2018.

10. B. I. Kopylov, Mathematical Models of Electric Machines. Moscow: Vysshaya shkola, 1987 [in Russian]

11. A.A. Zhelezniak, L. N. Bezmennikova, V.A. Zhukov and V.L. Erofeev, "Diagnosis of Thermal Processes in Motors of the Electrical Objects" in International Conference on Information 
Technologies in Business and Industry, Journal of Physics. Series 803, Tomsk Polytechnic University, Tomsk. Russia, 2017, pp. 012184-012190.

12. V.V. Prus, M.V. Zagirnyak, I.A. Kolotylo, D. Miljavec, "Estimate and taking into account change of steel losses in induction motors in process of their aging", in Proceedings of International IEEE Conference EUROCON, Saint Petersburg, 2009, pp 790-795.

13. X. Ge, Z. Q. Zhu, J. B. Li, and J. T. Chen, "A spoke-type IPM machine with novel alternate airspace barriers and reduction of unipolar leakage flux by step-staggered rotor" , in IEEE International Electric Machines Drives Conference (IEMDC), Coeur d'Alene, ID, USA, May 2015, pp. 53-59.

14. Xypteras, J.; Hatziathanassiou, V. "Thermal analysis of an electrical machine taking into account the iron losses and the deep-bar effect", IEEE Trans. Energy Conver,.vol.14, pp. 996-1003,1999.

15. V. Lyashenko, E. Kobilskaya, O. Demyanchenko, "Mathematical Model with complex heat transfer conductions in the spherical area", Transactions of Kremenchuk Mykhailo Ostrohradskyi National University, vol. 6/2017 (106), pp. 37-43, 2017. [in Ukrainian]

16. Jeffery Cooper, Introduction to Partial Differential Equations with MATLAB.Boston: Birkhäuser, 1998.

17. V.E. Shmelev, Partial differential equations toolbox. Toolbox for solution of differential equations in partial derivatives [in Russian]. http://matlab.exponenta.ru/pde/book1/index.php[in Russian]

18. F. Hurtado, M. Noy, J. Urrutia. "Flipping edges intriangulations", Urrutia Discrete \& Computational Geometry, vol.22 (3), 333-346, 1999.

\section{ЛІТЕРАТУРА}

1. Peixin Liang, Feng Chai, Yi Li, and Yulong Pei. Analytical Prediction of Magnetic Field Distribution in Spoke-Type Permanent-Magnet Synchronous Machines Accounting for Bridge Saturation and Magnet Shape. IEEE Trans.on Industrial Electronics. 2017. Vol. 64, Issue: 5. P. 3479- 3488 .

2. Eklund Petter, Sjölund Jonathan, Eriksson Sandra, Leijon Mats. Magnetic End Leakage Flux in a Spoke Type Rotor Permanent Magnet Synchronous Generator. International Scholarly and Scientific Research \& Innovation. 2017. Vol. 11, № 3. P. 605-610.

3. Peixin Liang,Yulong Pei, Feng Chaiand Shukang Cheng. Equivalent stator slot model of temperature field for high torque-density permanent magnet synchronous in-wheel motors accounting for winding type. COMPEL International Journal of Computations and Mathematics in Electrical. 2016. Vol.35, № 2. P. 713-727.

4. Bracikowski N., Hecquet M., Brochet P., and Shirinskii S. V.. Multiphysics Modeling of a Permanent Magnet Synchronous Machine by Using Lumped Models. IEEE Trans. Ind. Electron. 2012. Vol. 59, № 6. P. 2426-2437.

5. Sun T., Wang J. Extension of Virtual-Signal-Injection-Based MTPA Control for Interior Permanent-Magnet Synchronous Machine Drives Into the Field-Weakening Region. IEEE Trans. Ind.Electron. 2015. Vol. 62, № 11. P. 6809-6817.

6. Jingang Bai, Yong Liu, Yi Sui, Chengde Tong, Quanbin Zhao and Jiawei Zhang. Investigation of the Cooling and Thermal-Measuring System of a Compound-Structure Permanent-Magnet Synchronous Machine. Energies. 2014. Vol. 7. P. 1393-1426.

7. Lyashenko Viktor, Kobilskaya Elena, Martynenko Maryna And Demyanchenko Olga. Thermal process mathematical model in electrical machine. Modern Electrical and Energy Systems (MEES): 2017 year: Proceedings of the International Conference, 15-17 Nov. 2017. Kremenchuk: KrNU, 2017. P. 296-299.

8. Zaika A., Hrytsiuk O., Kobilskaya E., and Lyashenko V. The generalized mathematical model of heat conduction in a complex multi-layered area. AIP Conference Proceedings. 2017. Vol. 1895. P. 090004-090014.

9. Zaika A., Demyanchenko O., Hrytsiuk O., Kobilskaya E., and Lyashenko V., Hryhorova T.. Mathematical model of heat transfer in an electric machine. AIP Conference Proceedings. 2018. Vol. 2025. P. 080006-1-080006-7.

10. Копылов И.П. Математическое моделирование электрических машин: Учеб. для вузов. Москва: Высшая шк., 1987248 с. 
11. Zhelezniak A.A., Bezmennikova L. N., Zhukov V.A. and Erofeev V.L. Diagnosis of Thermal Processes in Motors of the Electrical Objects. International Conference on Information Technologies in Business and Industry: 2017 year: Journal of Physics: Conference Series, Vol. 803, 21-26 September 2016. Tomsk, Russian Federation. P. 012184-012190.

12. Prus V.V., Zagirnyak M.V., Kolotylo I.A., Miljavec D. Estimate and taking into account change of steel losses in induction motors in process of their aging EUROCON: 2009 year: Proceedings of International IEEE Conference, 18-23 May 2009. Saint Petersburg, Russian Federation. P. 790 795.

13. X. Ge, Z. Q. Zhu, J. B. Li, and J. T. Chen. A spoke-type IPM machine with novel alternate airspace barriers and reduction of unipolar leakage flux by step-staggered rotor. IEEE International Electric Machines Drives Conference (IEMDC): 2015 year: Proceedings of IEMDC, 10-13 May 2015. Coeur d'Alene, ID, USA. P. 53-59.

14. Xypteras J., Hatziathanassiou V. Thermal analysis of an electrical machine taking into account the iron losses and the deep-bar effect. IEEE Trans. Energy Convers. 1999. № 14. P. 996-1003.

15. Кобильська О. Б., Ляшенко В. П, Дем'янченко О. П. Математичні моделі теплообміну з умовами імпедансного типу у багатошарових областях. Вісник KpHУ iм. $M$. Остроградського. 2017. Вип. 6, Ч. 1. С. 37-43.

16. Cooper Jeffery. Introduction to Partial Differential Equations with MATLAB. Boston: Birkhäuser, $1998.533 \mathrm{p}$.

17. Шмелев B. E. Partial Differential Equations Toolbox. Инструментарий решения дифференциальных уравнений в частных производных: учебное пособие. URL:http://matlab.exponenta.ru/pde/index.php

18. Hurtado F., M. Noy, J. Urrutia. Flipping edges intriangulations. Discrete \& Computational Geometry.1999. Vol. 22 (3). P 333-346.

Дем'янченко Ольга Пантеліївна-старший викладач кафедри природничонаукових та гуманітарних дисииплін, Азовський морський інститут Національного університету "Одеська морська академія",вул. Чорноморська, 19, м. Маріуполь Украӥна, 87517; e-таil: olgademyanchenko@gmail.com; ORCID: 0000-0002-4693-0364

Дем'янченко Ольга Пантеліївна -старший преподаватель кафедры естественнонаучных и гуманитарных дисииплин, Азовский морской институт Национального университета "Одесская морская академия", ул. Черноморская, 19, г.. Мариуполь Украина, 87517; e-таil: olgademyanchenko@gmail.com; ORCID:0000-0002-4693-0364

Demyanchenko Olga Panteleivna - Senior Lecturer, Department of "Natural Science and Humanitarian Disciplines", Mariupol, Azov maritime institute of Nationaluniversity "Odessa maritime academy" 19, Chornomors'ka str. Ukraine, 87517, Mariupol e-mail: olgademyanchenko@gmail.com; ORCID: 0000-0002-4693-0364

Кобильська Олена Борисівна - кандидат фізико-математичних наук, доцент; доцент кафедри інформатики і вищої математики, Кременчуцький начіональний університет ім. Михайла Остроградського, вул. Першотравнева, 20, м. Кременчук, 61046, Украӥна; е-таil: kobilskaya1983@gmail.com; ORCID:0000-0002-4210-1534.

Кобыльская Елена Борисовна-кандидат физико-математических наук, доцент; доцент кафедры информатики и высшей математики, Кременчугский начиональный университет им. Михаила Остроградского, ул. Первомайская, 20 39600, г. Кременчуг, Украина; е-таil: kobilskaya1983@gmail.com; ORCID:0000-0002-4210-1534.

Kobilskaya Elena Borisovna- Candidate of Physical and Mathematical Sciences, Associate Professor of the Department of Mathematics and Computer Science, Kremenchuk National University named after Mikhail Ostrogradsky, 39600, 20, Pershotravneva Street, Kremenchuk, Ukraine; e-mail: kobilskaya1983@gmail.com; ORCID:0000-0002-4210-1534. 
Ляшенко Віктор Павлович - доктор технічних наук, професор; завідувач кафедри інформатики і вищої математики, Кременчуцький національний університет ім. Михайла Остроградського, вул. Першотравнева, 20, м. Кременчук, 61046, Україна; е-таil: viklyash2903@gmail.com; ORCID: 0000-0002-4538-631X

Ляшенко Виктор Павлович- доктор технических наук, профессор заведующий кафедрой информатики и высшей математики, Кременчугский национальный университет им. Михаила Остроградского, ул. Первомайская, 20, г. Кременчук, 61046, Украина; е-таil: viklyash2903@gmail.com; ORCID: 0000-0002-4538-631X

Lyashenko Viktor Pavlovich-Doctor of Technical Science, Professor, Head of Department of Department of Mathematics and Computer Science, Kremenchuk National University named after Mikhail Ostrogradsky, 39600, 20, Pershotravneva Street, Kremenchuk, Ukraine; e-mail: viklyash2903@gmail.com; ORCID: 0000-0002-4538-631X

Набок Тетяна Андреївна - старший викладач кафедри інформатики і вищої математики, Кременчуцький національний університет ім. Михайла Остроградського, вул. Першотравнева, 20, м. Кременчук, 61046, Україна; e-mail: nabok@gmail.com; ORCID: 0000-0002-1501-9009

Набок Татьяна Андреевна - старший преподаватель кафедры информатики и высшей математики, Кременчугский национальный университет им. Михаила Остроградского, ул. Первомайская, 20 39600, г. Кременчуг, Украина; e-mail: nabok@gmail.com; ORCID: 0000-00021501-9009

Nabok Tatyana Andreevna - Senior Lecturer, of the Department of Mathematics and Computer Science, Kremenchuk National University named after Mikhail Ostrogradsky, 39600, 20, Pershotravneva Street, Kremenchuk, Ukraine; e-mail: nabok@gmail.com; ORCID: 0000-0002-15019009 